\title{
Sistem Informasi Penjualan dan Promosi Kayu Bangunan dan Rumah Berbasis Web
}

\author{
${ }^{1}$ Fitriyanti Suleman, ${ }^{2}$ Nur Oktavin Idris, ${ }^{3}$ Siti Andini Utiarahman \\ ${ }^{1,2}$ STMIK Ichsan Gorontalo, ${ }^{3}$ Universitas Ichsan Gorontalo, Indonesia

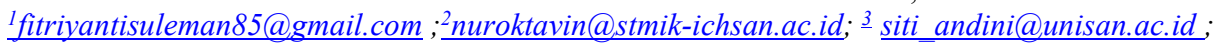

\begin{tabular}{l} 
Article Info \\
\hline Article history: \\
Received, 18/11/2021 \\
Revised, 20/11/2021 \\
Accepted, 30/11/2021 \\
\hline Kata Kunci: \\
Sistem informasi \\
penjualan \\
promosi \\
kayu
\end{tabular}

Keywords:

Information system

sale

promotion

lumber

\begin{abstract}
ABSTRAK
Kayu merupakan bahan utama yang digunakan untuk kebutuhan tiang penyangga, pembuatan tiang atap, kusen, daun pintu, daun jendela dan lainnya. Salah satu jenis usaha industri kecil yang bergerak di bidang penjualan kayu yaitu Wana Lestari Dua. Pemasaran yang dilakukan oleh Wana Lestari Dua masih secara tatap muka atau hanya dilakukan di tempat usaha dengan lingkup pembeli yang meliputi wilayah kecamatan Kwandang, dan belum menggunakan promosi secara online. Sehingga belum ada akses secara meluas ke pelanggan lain di luar wilayah tersebut. Oleh karenanya itu dibutuhkan sistem penjualan dan promosi yang mampu dijangkau pelanggan lainnya. Dimana penelitian ini bertujuan merancang sebuah sistem informasi penjualan dan promosi kayu bangunan dan rumah yang berbasis web. Penelitian ini merujuk pada penggunaan waterfall method. Data yang diperoleh dengan cara melakukan observasi, teknik wawancara dan mengumpulkan referensi sebagai pendukung. Hasil dari penelitian dengan sistem yang dirancang dapat memudahkan pelanggan untuk melakukan pemesanan kayu serta memudahkan perusahaan industri kayu dalam melakukan promosi.
\end{abstract}

\section{ABSTRACT}

Lumber is considered the main material used to make supporting poles, roof poles, door frames, doors, windows frames, and so on. One of the small manufacturers engaged in lumber marketing is Wana Lestari Dua. And yet, Wana Lestari Dua is operating offline or on-site marketing, reaching only subdistrict-range customers, especially those who live in Kwandang. Additionally, there are no online promotions and proper access for customers not living in the subdistrict. Accordingly, this research provides a design of an information system for web-based lumber marketing and promotion. It applies the waterfall method. Data are collected by observation, technik interview, and using references, the latest of which vesting supporting data. The result, or the system designed, is envisaged to enable customers to order lumber easily and allow lumber manufacturers to promote products more efficiently.

\section{Penulis Korespondensi:}

Fitriyanti Suleman,

Program Studi Sistem Informasi,

STMIK Ichsan Gorontalo,

Email: fitriyantisuleman@gmail.com

\section{PENDAHULUAN}

Memenuhi tuntutan global saat ini (baik rentang produk yang luas, kualitas tinggi dan harga yang kompetitif) memaksakan pengembangan produk cepat dan manufacturing [1]. Industri pengolahan kayu merupakan industri yang dominan berorientasi produksi. Sehingga kebutuhan sistem informasi dapat meningkatkan produktivitas. Kayu adalah bahan utama yang digunakan untuk kebutuhan tiang penyangga, pembuatan tiang atap, kusen, daun pintu, daun jendela dan lainnya [2]. Banyak petani sebagai pemasok kayu menawarkan beragam jenis maupun ukuran kayu untuk dijual [3].

Wana Lestari Dua merupakan usaha industri kecil yang bergerak di bidang penjualan kayu bangunan. Untuk pemasaran biasanya langsung dilakukan ditempat usaha dengan lingkup pembeli yang meliputi wilayah 
kecamatan kwandang. Melihat saat ini cara pelanggan memiliki akses tak terbatas keberbagai informasi termasuk berbagai aktivitas iklan produk [4]. Sehingga diperlukan sistem penjualan dan promosi berbasis teknologi web.

Tujuan penelitian merancang sistem informasi penjualan dan promosi kayu bangunan dan rumah berbasis web. Penjualan adalah tujuan dari rangkaian pemasaran, sebab pada tahapan ini yakni pemberian nilai tukar barang, negosisasi dan juga perjanjian bersama, serta tata cara penyelesaian yang telah disepakati bersama untuk mencapai kepuasan [5]. Pemanfaatan penjualan berbasis web dapat meningkatkan jumlah keuntungan [6]. Promosi adalah bentuk komunikasi pemasaran yang mempunyai tujuan menyebarkan, memberikan informasi dan mempengaruhi konsumen sehingga tertarik terhadap produk yang ditawarkan [7].

Sistem dan informasi merupakan rangkaian penggabungan diantara urutan cara, isu, pelaku serta kecanggihan teknologi yang kemudian diorganisasikan guna mencapai suatu hasil tertentu di dalam organisasi [8]. Web adalah kumpulan berbagai halaman yang isinya adalah informasi yang dapat disimpan di internet yang dapat diakses maupun dilihat dengan menggunakan jaringan internet itu sendiri sebagai contoh yaitu komputer [9].

Penelitian oleh Minda Septiani dkk [2] Tujuan penelitian yaitu merancang sistem informasi pejualan yang dapat diakses pelanggan selama 24 jam secara mudah hanya dengan mengunjungi halaman website. Metode penelitian yang digunakan waterfall metode. Menggunakan Entity Relationship Diagram (ERD) sebagai rancangan basis data relational, Logical Record Structure (LRS) untuk model sistem.

Penelitian Ariyanto [10]. Tujuan penelitian membuat sistem informasi penjualan untuk membanatu memperluas jangkauan pemasaran, meningkatkan keuntungan bagi perusahaan. Sistem dirancang menggunakan Javascript, PHP, MySQL, dan CSS. Menggunakan metode waterfall dan hasil penelitian menyatakan sistem membantu dalam mempromosikan produk kayu jati berdasarkan hasil quisioner $81 \%$ setuju.

Penelitian oleh Antika Fusiba Raning [11]. Tujuan penelitian untuk merancang system penjualan berbasis online yang digunakan untuk memberikan informasi berupa jenis serta kondisi kayu yang terdapat di UD Karya Bakti dan untuk mempromosikan serta melakukan pencatatan penjualan. Menggunakan diagram konteks dan use case untuk perancangan sistem. Hasil penelitian sistem dapat menginformasikan data stok kayu yang di tawarkan dan dapat pula melakukan pemesanan dan dikonfirmasi oleh admin.

Penelitian oleh I.G.T. Isa [12]. Merancang aplikasi berupa e-commerce kayu di sebuah PT. Sekar Gayanti Utama berbasis website. Pengembangan sistem dilakukan dengan metode waterfall dengan bentuk pemodelan Diagram Konteks, Data Flow Diagram, perancangan tampilan antar muka pengguna dan perancangan basis data. Hasil penelitiannya berupa aplikasi penjualan kayu berbasis web.

Berdasarkan uraian dari penelitian terkait yang terurai, memiliki perbedaan dengan penelitian sekarang yakni pada objek penelitian dimana penelitian ini mengambil lokasi penelitian pada perusahaan industri kayu Wana Lestari Dua dan tidak menggunakan kuesioner untuk mengetahui apakah sistem yang dirancang dapat membantu dalam mempromosikan produk kayu sebagai bahan bangunan dan rumah, tetapi berdasarkan komentar pengguna dari sistem informasi tersebut.

\section{METODE PENELITIAN}

\subsection{Motode Analisis Sistem}

Penelitian ini menggunakan cara kerja model waterfall yang penerapannya menggunakan metode pengembangan sistematik dan sistem informasi sequensial[13]. Waterfall mempunyai kelebihan dalam mendapatkan hasil kerja sistem perangkat lunak yang baik karena melewati beberapa tahapan seperti yang diilustrasikan pada gambar dibawah ini. Berikut ini adalah model alur kerja model waterfall [14] :

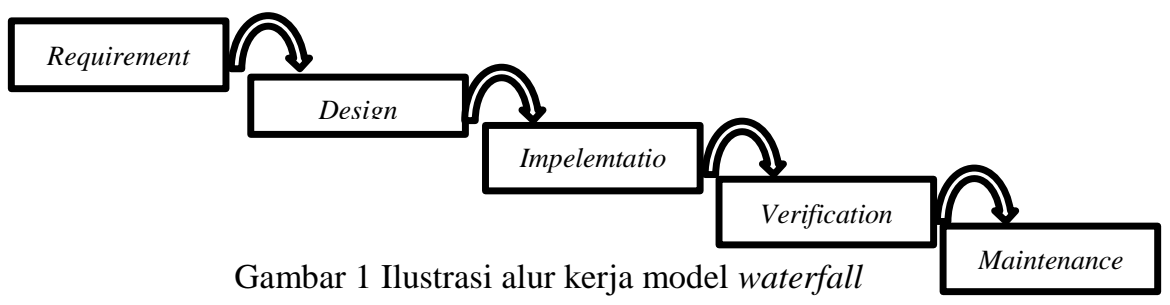

\subsection{Metode Pengumpulan Data}

Berikut adalah beberapa tahapan pengumpulan data : 
a. Melakukan wawancara dengan cara tanya jawab langsung oleh pemilik serta harapan yang diinginkan untuk proses penjualan dan promosi usaha yang dimiliki.

b. Melakukan observasi dengan cara datang langsung ke Mebel Wana Lestari Dua untuk mengetahui alur bisnis

c. Mengumpulkan referensi, mengumpulkan informasi beserta teori pendukung lainnya.

\section{HASIL DAN ANALISIS}

\subsection{Analisis Sistem}

Rancangan sistem diusulkan diawali dengan admin yang melakukan login untuk dapat masuk ke sistem dan admin yang melakukan pengimputan data jenis kayu, input harga kayu dan informasi tentang kayu, melakukan update data mengenai jenis kayu dan harga kayu. Admin dapat bertransaksi dengan data pemesanan yang dilakukan pembeli, melihat data pembayaran serta mengkonfirmasi pembayaran. Untuk pembeli juga melakukan registrasi dan login untuk masuk ke sistem. Melihat informasi dan ketersediaan kayu, menemukan kayu yang diinginkan, melakukan pemesanan dan pembelian, melakukan pembayaran dan menunggu konfirmasi dari penjual yang akan dilakukan oleh admin. Semua transaksi akan dibuatkan laporan. Penjelasan diatas diilustrasikan pada gambar berikut

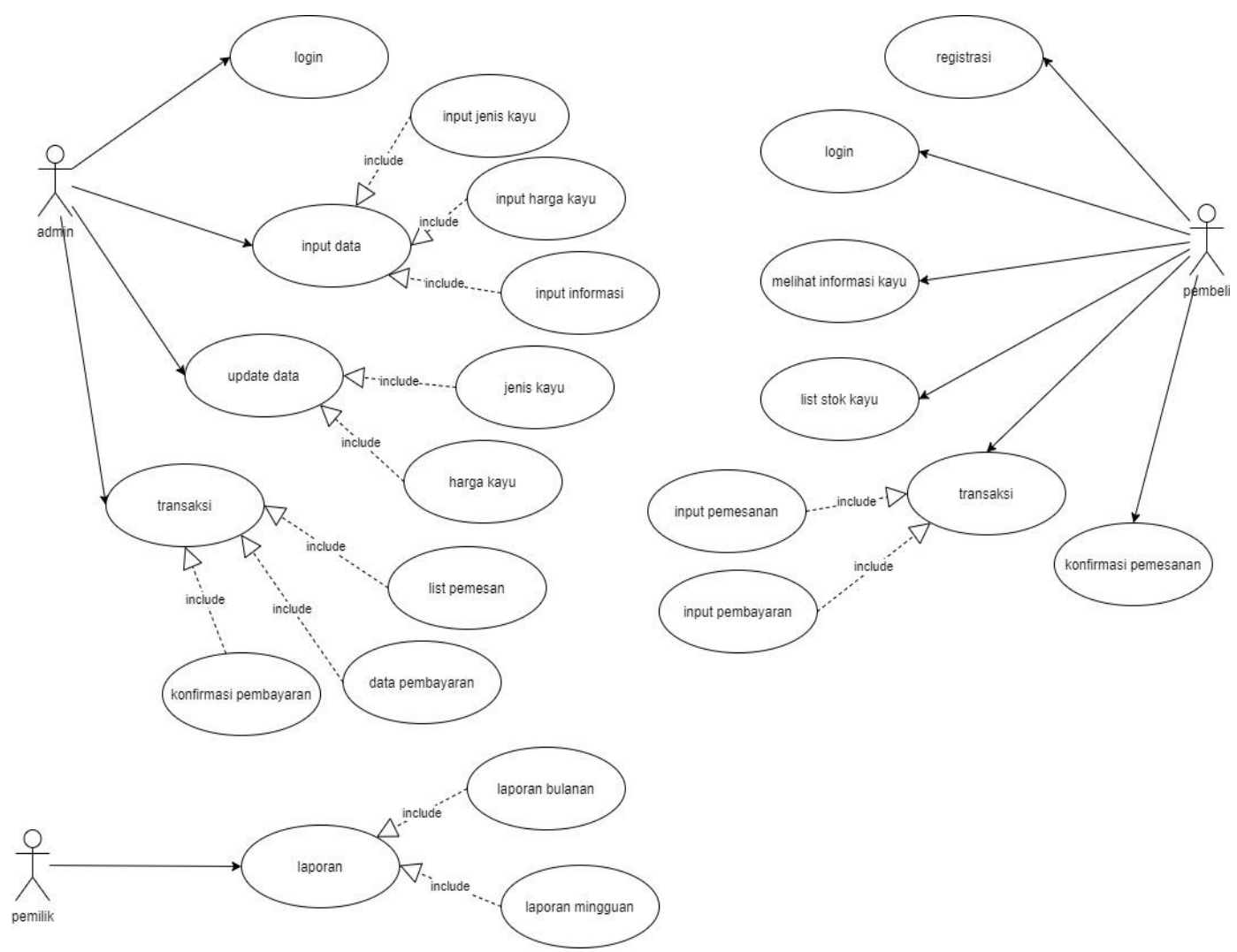

Gambar 2 sistem yang diusulkan 
JSAI : Journal Scientific and Applied Informatics

Vol. 4, No. 3, November 2021, hal. 378 382

E-ISSN: 2614-3054; P-ISSN: 2614-3062, Terkakreditasi Kemenristekdikti, Sinta 5

\subsection{Hasil Perancangan Sistem}

\subsubsection{Desain GUI}

GUI (Graphical User Interface) adalah sebuah antarmuka pengguna menggunakan metode interaksi pada piranti elektronis dengan cara grafis antara user dan komputer [15]. Tampilan sistem yang dirancang digunakan untuk mengoptimalkan kemudahan user. Berikut diantara contoh tampilan halaman data kayu dari admin dan tampilan jenis kayu dan tampilan pemesanan kayu dari pelanggan.

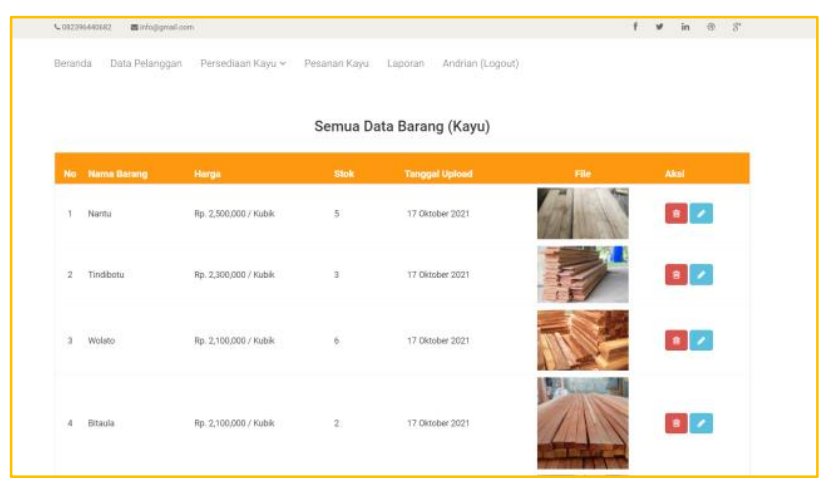

Gambar 3 Halaman Olah Data Kayu

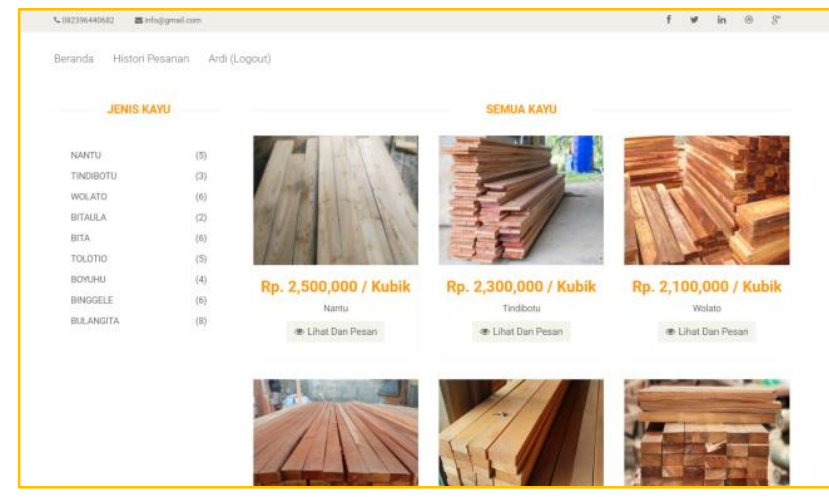

Gambar 4 Halaman Data dan Jenis Kayu

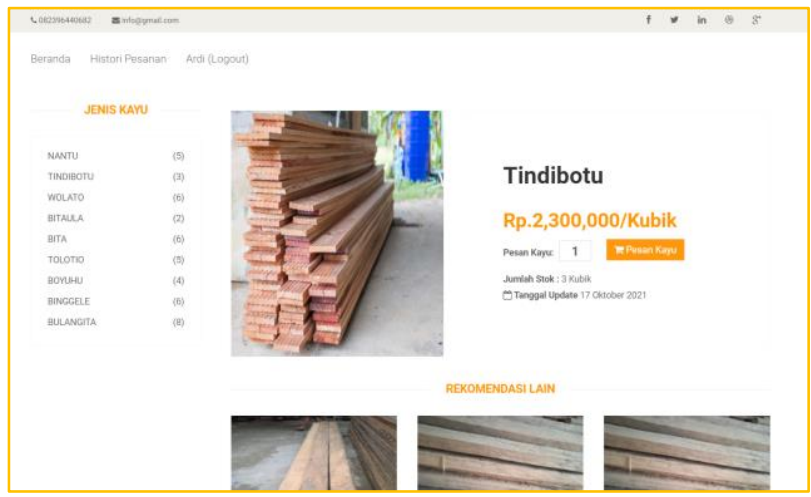

Gambar 5 Halaman Pesan Kayu

\section{KESIMPULAN}

Sistem yang dirancang dapat memudahkan pelanggan untuk melakukan pemesanan kayu dan promosi kayu. 


\section{REFERENSI}

[1] I. Perić, P. Grošelj, A. Sujová, M. Kalem, K. Greger, and J. Kropivšek, "Analysis of implementation of integrated information systems in Croatian wood processing industry," Drv. Ind., vol. 70, no. 2, pp. 129-139, 2019, doi: 10.5552/drvind.2019.1911.

[2] M. Septiani, R. Aulianita, V. Sofica, and N. Hasan, "Sistem Informasi Penjualan Kayu Kusen Berbasis Website,” vol. 9, no. 2, pp. 103-107, 2021.

[3] A. Jamil, “Daftar Harga Kayu Bangunan,” Supplier Kayu Indonesia, 2021. .

[4] A. Rumondang, Pemasaran Digital dan Perilaku Konsumen, 1st ed. Yayasan Kita Menulis, 2020.

[5] D. S. Soegoto and C. Cica, "Design of Web-based Sales Information System on Fashion Shop in Bandung, Indonesia," IOP Conf. Ser. Mater. Sci. Eng., vol. 407, no. 1, 2018, doi: 10.1088/1757899X/407/1/012023.

[6] H. ) T. S. H. E. W. 3) Susianawati, "Rancang Bangun Sistem Informasi Penjualan Berbasis Web Pada Cv. Gemilang Indonesia," J. Jsika, vol. 6, no. 1, p. ISSN 2338-137X, 2017.

[7] H. Rohaeni, "Peranan Promosi Melalui Personal Selling Terhadap Volume Penjualan," Ecodemica, vol. IV, no. 2, pp. 223-231, 2016.

[8] M. Ferdika and H. Kuswara, "Sistem Informasi Penjualan Berbasis Web Pada PT Era Makmur Cahaya Damai Bekasi," Inf. Syst. Educ. Prof. E-ISSN 2548-3587, vol. 1, no. 2, pp. 175-188, 2017.

[9] M. Ahmia and H. Belbachir, "p, q-Analogue of a linear transformation preserving log-convexity," Indian J. Pure Appl. Math., vol. 49, no. 3, pp. 549-557, 2018, doi: 10.1007/s13226-018-0284-5.

[10] Ariyanto, "SISTEM INFORMASI PENJUALAN KAYU JATI BERDASARKAN VOLUME (METER KUBIK) PADA CV. JATI MULYO BERBASIS WEB," eprints.ums.ac.id, vol. 85, no. 1, 2016.

[11] A. F. Raning and H. Fitriyadi, "Sistem Informasi Penjualan Kayu Pada UD Karya Bakti Berbasis Web," Jutisi, vol. 3, no. 3, pp. 617-624, 2014.

[12] I. G. T. Isa, "Perancangan aplikasi e-commerce penjualan kayu pada pt. sekar gayanti utama berbasis web," Jasisfo (Jurnal Sist. Informasi), vol. 2, no. 1, pp. 127-140, 2021.

[13] G. W. Sasmito, "Penerapan Metode Waterfall Pada Desain Sistem Informasi Geografis Industri Kabupaten Tegal," J. Inform. Pengemb. IT, vol. 2, no. 1, pp. 6-12, 2017.

[14] S. A. Utiarahman and S. D. Ali, "Sistem Informasi Geografis Potensi Sumber Daya Alam di Wilayah Kabupaten Banggai Kepulauan Berbasis Android," J. Inform. Upgris, vol. 6, no. 1, 2020, doi: 10.26877/jiu.v6i1.5221.

[15] I. Kurniastuti and A. Andini, "Perancangan Program Penentuan Histogram Citra Dengan Graphical User Interface (Gui)," Appl. Technol. Comput. Sci. J., vol. 1, no. 1, pp. 11-17, 2018, doi: 10.33086/atcsj.v1i1.4. 